\title{
PENARAPAN PRINSIP SYARIAH PADA AKAD RAHN DI LEMBAGA PEGADAIAN SYARIAH
}

\author{
Maman Surahman dan Panji Adam \\ Fakultas Syariah \\ Universitas Islam Bandung \\ Abuazkaalmadani@gmail.com
}

\begin{abstract}
Abstrak
$\mathrm{G}$ adai sebagai salah satu kategori dari perjanjian utang-piutang, untuk suatu kepercayaan dari kreditur, maka debitur menggadaikan barangnya sebagai jaminan terhadap utangnya itu. Barang jaminan tetap milik orang yang menggadaikan, namun dikuasai oleh penerma gadai. Mekanisme teknis gadai syariah, maka secara teknis operasional dapat dilakukan oleh suatu lembaga keungan syariah, yaitu pegadaian syariah, baik sebagai lembaga swasta maupun pemerintah. Dalam hal ini penulis bermaksud untuk melakukan analisis penerapan konsep dan prinsip-prinsip syariah yang teraplikasikan pada akad gadai di lembaga pegadaian syariah. Tujuan penelitian ini adalah untuk: pertama, untuk mengetahui konsep gadai dalam literatur fikih klasik; kedua, untuk mengetahui penerapan prinsip syariah pada akad rahn di lembaga pegadaian sayriah. Metode pendekatan yang digunakan dalam penelitian ini adalah yuridis normatif dengan sifat penelitiandeskriptif analisis. Jenis data yang digunakan dalam penelitian ini adalah jenis data primer dan sekunder. Penelitian ini digolongkan kepada jenis penelitian kualitiatif.Hasil penelitian menyimpulkan bahwa, pertama, konsep gadai dalam literatur fikih klasik dinamai dengan istilah rahn, landasan yuridis kebasahan transkasi/akad gadai dalam Islam terdapat dalam al-Quran surat alBaqarah: 283, yang secara eksplisit menerangkan hukum gadai, selain terdapat di dalam al-Quran landasan yuridis keabsakan akad gadai/rahn terdapat di dalam beberapa hadis Nabawi serta konsensu/ijma' para ulama tenteng hal tersebut; kedua, prinisp-prinsip syariah di diterapkan dalam sistem pegadaian syariah ada 3 (tiga) prinsip, yaitu: prinsip tauhid, prinsip tolong-menolong (ta'awun) dan prinsip bisnis (tijariah).
\end{abstract}

Kata Kunci: Prinsip Syariah, Gadai, Pegadaian Syariah

\section{PENDAHULUAN}

\section{Latar Belakang}

Lembaga keuangan berperan penting dalam pengembangan dan pertumbuhan masyarakat industri modern. Produksi berskala besar dengan kebutuhan investasi yang membutuhkan modal yang besar tidak mungkin dipenuhi tanpa bantuan para pengusaha untuk mendapatkan tambahan modalnya melalui mekanisme kredit dan menjadi tumpuan investasi mekanisme saving. ${ }^{1}$

Lembaga keuangan adalah setiap perusahaan yang bidang usahanya hanya bergerak di bidang keuangan. Lembaga keuangan dibagi menjadi dua yaitu lembaga keuangan bank dan lembaga keuangan bukan bank. Lembaga keuangan bank adalah Bank Sentral, Bank Umum, dan BPR, sedangkan lembaga keuangan bukan bank yaitu asuransi, leasing, anjak piutang (factoring), modal ventura, pegadaian, dana pensiun, pasar modal, reksa dana, kartu kredit dan lembaga pembiayaan konsumen.

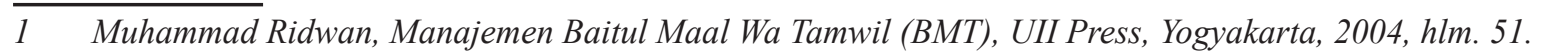


Di Indonesia terdapat dua lembaga keuangan yaitu lembaga keuangan konvensional dan lembaga keuangan Syari'ah. Lembaga keuangan (Financial Institution) adalah suatu perusahaan yang usahanya bergerak di bidang jasa keuangan. Artinya kegiatan yang dilakukan oleh lembaga ini akan selalu berkaitan dengan bidang keuangan, apakah penghimpunan dana, menyalurkan, dan/atau jasa-jasa keuangan lainnya. ${ }^{2}$

Lembaga keuangan konvensional ialah lembaga keuangan yang kegiatan usahanya dilakukan secara konvensional. Adapun lembaga keuangan Syari'ah adalah lembaga keuangan yang menjalankan kegiatan usahanya dilakukan berdasarkan prinsip Syari'ah.

Menurut pasal 1 angka 12 Undang-Undang Nomor 21 Tahun 2008 yang di maksud dengan prinsip Syari'ah adalah:

"Prinsip hukum Islam dalam kegiatan perbankan berdasarkan fatwa yang dikeluarkan oleh lembaga yang memiliki kewenangan dalam penetapan fatwa di bidang syari'ah".

Dari ketentuan di atas tampak bahwa menurut Undang-Undang Nomor 21 Tahun 2008, prinsip hukum Islam yang akan digunakan dalam kegiatan yang dijalankan oleh lembaga keuangan Syari'ah terlebih dahulu harus ditetapkan dalam fatwa, yang dalam hal ini adalah Fatwa Dewan Syariah Nasional (DSN) Majelis Ulama Indonesia.

Salah satu produk lembaga keuangan Syariah (LKS) adalah "pembiayaan” yang dalam hukum Islam (baca: fikih) kepentingan kreditur itu sangat dijaga dan diperhatikan. Oleh karena itu, ia dibolehkan meminta 'barang' dari debitur sebagai jaminan utangnya. Dalam dunia finansial, barang jaminan ini biasa dikenal dengan objek jaminan (colleteral) atau barang gadai (marhun) dalam Gadai Syariah.

Gadai sebagai salah satu kategori dari perjanjian utang-piutang, untuk suatu kepercayaan dari kreditur, maka debitur menggadaikan barangnya sebagai jaminan terhadap utangnya itu. Barang jaminan tetap milik orang yang menggadaikan, namun dikuasai oleh penerma gadai.

Mekanisme teknis gadai syariah, maka secara teknis operasional dapat dilakukan oleh suatu lembaga keungan syariah, yaitu pegadaian syariah, baik sebagai lembaga swasta maupun pemerintah. Dalam hal ini penulis bermaksud untuk melakukan analisis penerapan konsep dan prinsip-prinsip syariah yang teraplikasikan pada akad gadai di lembaga pegadaian syariah.

\section{Identifikasi Masalah}

a. Bagaimana konsep gadai dalam literatur fikih klasik?

b. Bagaimana penerapan prinsip syariah pada akad rahn di lembaga pegadaian sayriah?

\section{PEMBAHASAN}

\section{Konsep Gadai dalam Literatur Fikih Klasik}

\section{a. Definisi Gadai (Rahn)}

Dalam hukum Islam (baca: fikih) konsep gadai disebut dengan istilah rahn. Kata al-

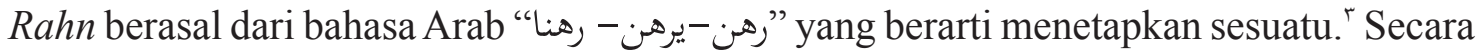
bahasa rahn adalan al-tsubût wa al-dawâm yang berarti "tetap" dan "kekal". Menurut Taqiy al-Din Abu Bakar al-Husaini, al-rahn adalah al-tsubût yakni sesuatu yang tetap dan al-ihtibas yaitu menahan sesuatu. ${ }^{\circ}$ Menurut al-Buthi rahn secara etimologi adalah sebagai berikut:

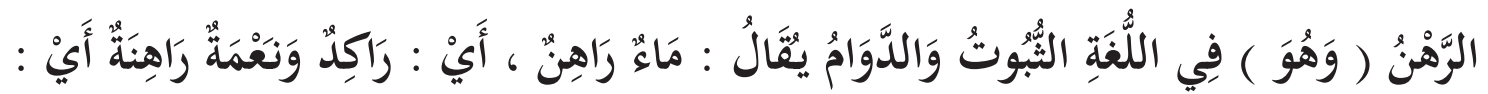

2 Kasmir, Bank dan Lembaga Keuangan Lainnya, Rajawali Press, Jakarta, 1998, hlm. 2.

3 Louis Maluf, al-Munjid Lughah wa al-A'lâm, Dar al-Masyark, Beirut, 1986, hlm. 284.

4 Abu Zakariya Yahya Ibn Syarif al-Nawawi, Mughni al-Muhtâj, Musthafa al-Babi al-Halabi, Mesir, 1957, juz. II, hlm. 121.

5 Taqiyuddin Abu Bakar al-Husaini, Kifâtat al-Akhyâr fî Hall al-Ikhtishâr, Dar al-Khair, Damaskus, 1994, hlm. 253. 


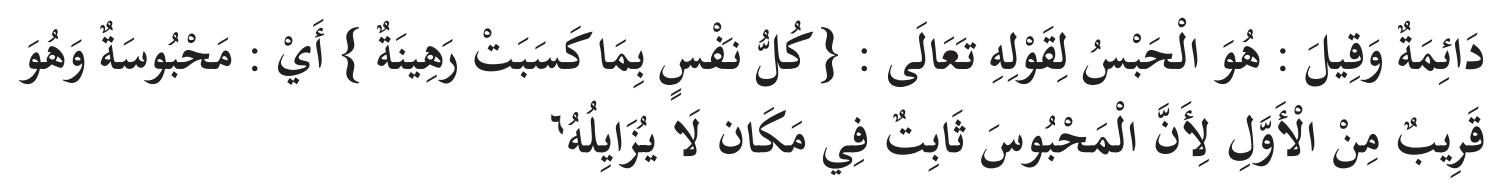

"Rahn secara bahasa berarti tetap dan kekal; dikatakan mâun râhinun (air yang mengenang); na'matun râhinatun (yang abadi). Dikatakan pula bahwa rahn berarti menahan, berdasarkan firman Allah "Tiap-tiap diri bertanggung jawab atas apa yang telah diperbuatnya" maksudnya adalah tertahan. Rahn lebih cenderung kepada arti pertama, karena tertahan berarti tetap dan tidak berpindah sedikitpun".

Dengan demikian, pengertian rahn secara bahasa seperti yang terungkap di atas adalah tetap, kekal dan menahan suatu barang sebagai pengikat utang.

Secara istilah, al-rahn menurut al-Qurthubi adalah sebagai berikut:

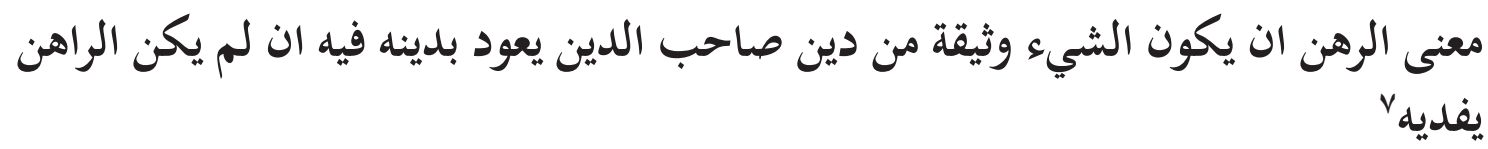

"Barang yang ditahan oleh pihak yang memberi utang sebagai bentuk jaminan dari orang yang berutang, sampai pihak yang berhutang melunasi utang tersebut”.

Menurut Ibn Qudamah rahn adalah sebagai berikut:

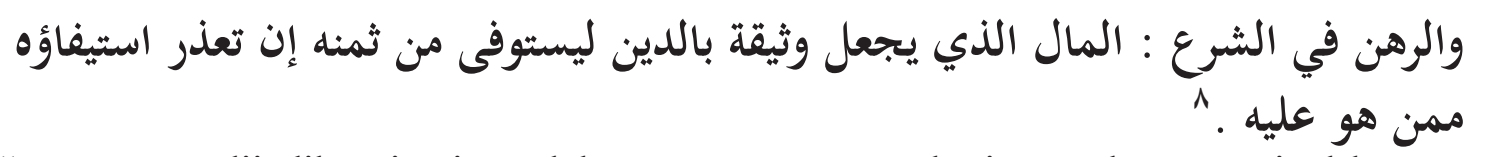

"Harta yang dijadikan jaminan dalam utang, agar pemberi tang dapat menjual barang tersebut apabila pihak yang berutang tidak mampu membaya utangnya".

Menurut ulama Syafi'iyah rahn adalah sebagai berikut:

والرهن لغة الثبوت وشرعا جعل عين مال وثيقة بدين يستوفى منها عند تعذر وفائهُ "menjadikan suatu barang yang dapat dijual sebagai bentuk jaminan utang dipenuhi dari harganya, apabila yang berutang tidak mampu membayar utangnya".

Menurut Wahbah al-Zuhaili, akad rahn secara syara'adalah:

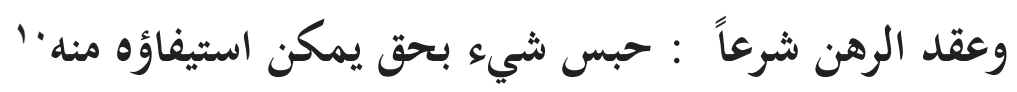

"Menahan sesuatu yang disertai hak untuk menafaatkannya".

Dengan pengertian tersebut, rahn menjadikan suatu barang sebagai pengikat utang yang dimungkinkan baginya untuk menganbil utang dengan cara menafaatkan barang jaminan tersebut. Bagi Wahbah, jenis barang yang dijaminkan harus berupa barang berharga yang memiliki nilai manfaat. Ukuran berharganya suatu barang, diukur dari kemungkinan diperolehnya nilai manfaat dari barang tersebut. ${ }^{11}$

$6 \quad$ Manshur Ibn Yunus Ibn Idris al-Buthi, Kasyf al-Qinâ' 'an matan al-Iqnâ', t.p, tt, tth, juz. X, hlm. 40.

7 Abu 'Amr Yusuf Ibn Abdullah Ibn Muhammad Ibn Abd al-Bar Ibn Ashim al-Numari al-Qurthubi, al-Kâfífì Fiqh ahl al-Madînah al-Mâlikî, Maktabah al-Riyadh al-Hadistah, Saudi Arabia, 1980, Juz. II, hlm. 812.

8 Abu Muhammad Abdullah Ibn Ahmad Ibn Muhammad Ibn Qudamah al-Maqdisi, al-Mughî wa yalihi al-Syrah al-Kabîr, Dar al-Hadits, Kairo, 2004, Juz. VI, hlm. 23.

9 Abu Bakar Ibn al-Sayyid Muhammad Syatha al-Dimyathi, I'ânt al-Thâlibîn 'alâ hil al-Fâdz Fath al-Mu'în Lisyarh Qurra al-'Ain, Dar al-Fikr, Beirut, t.th, Juz. III, hlm. 48.

10 Wahbah al-Zuhaili, al-Fiqh al-Islâmî wa Adllatuh, Dar al-Fikr, Beirut, 2012, Juz. V, hlm. 23.

11 Ibid. 
Berdasarkan definisi yang dipaparkan oleh para ulama di atas, dapat disimpulkan bahwa yang dimaksud dengan rahn adalah perjanjian penyerahan barang sebagai bentuk jamnan atas utang sehingga orang yang bersangkutan boleh mengambil utang. Dengan demikian, tampak bahwa fungsi dari barang jaminan adalah untuk memberikan keyakinan, ketenangan, dan keamanan atas utang yang dipinjamkannya.

\section{b. Landasan Yuridis Rahn}

Dasar hukum rahn sebagai kegiatan muamalah dapat merujuk pada dalil-dalil yang didasarkan pada al-Quran, hadis, ijmak, dan fatwa DSN-MUI. Dalam kitab al-Mu'jam al-Mufahras li al-Fâdz al-Qurân al-Karîm, ${ }^{12}$ setidaknya terdapat 3 (tiga) kata yang seakar dengan kata rahn dalam al-Quran, yaitu: (1) rahin dalam Q.S al-Thur (52): $21^{13}$ (2) rahina dalam Q.S al-Mudatsir (74): $38^{14}$ dan (3) farihan dalam Q.S al-Baqarah (2): 283. ${ }^{15}$ Dengan demikian, ketga termrahn tersebut, digunakan untuk menegaskan bahwa rahn merupakan konsekuensi dari sesuatu yang telah dijanjikan atau dilakukan.

Al-Zamakhsyari sebagaimana dikutip oleh Ade Sofyan Mulazid mengaitkan istilah rahin dengan kasb dalam Q.S al-Thur (51): 21, dan rahina dalam Q.S al-Mudatsir (74): 38. Dalam ilustrasi yang sederhana di mana pegadai (rahin) akan bertanggung jawab atas apa yang telah diperbuatnya. ${ }^{16}$

Lebih lanjut Ade menjelaskan bahwa term rahina dalam Q.S al-Mudatsir (74): 38 adalah penahanan suatu barang disebabkan oleh perilaku dari pemlik barang tersebut. Dengan kata lain, ia berpendapat bahwa diri seseorang akan tertahan utangnya sampai keadaan mampu melunasinya. ${ }^{17}$

Menurut Muhammad Ali Sayis bahwa kata farihan dalam Q.S al-Baqarah (2): 283 adalah petnjuk untuk menerapkan prinsip kehati-hatian dalam transaksi utang piutang berjangka. Kehati-hatian ditunjukan dengan cara menjaminkan sebuah barang kepada orang yang berpiutang (murtahin). Apabila transksi dilakukan saat kedua belah pihak dalam perjalanan (safar), maka transkasi tersebut harus dicatat dihadapan saksi. Bahkan ia menganggap bahwa dengan adanya barang jaminan, rahin telah melampui prinsio kehati-hatian suatu transaksi utang yang hanya ditulis dan dipersaksikan. ${ }^{18}$

Sekalipun demijkian, penerima gadai (murtahin) juga boleh tidak menerima jaminan (marhun) dari penggadai (rahin). Alasannya adalah murtahin yaknin bahwa rahin tidak akan menghindar dari kewajibannya. Sebab, substansi akad rahn adalah pencegahan terjadinya wanprestasi dari kedua belah pihak. ${ }^{19}$

Fungsi kata farihan dalam Q.S al-Baqqarah (2): 283 adalah untuk menjaga kepercayaan masing-masing pihak, sehingga penerima gadai (murtahin) meyakini bahwa: (1) penggadai (rahin) beritikad baik untuk mengembalikan pinjamannya (marhun bih) dengan cara menggadaikan barang atau benda yang dimilikinya (marhun), serta; (2) ia tidak melalaikan janji pengembalian utangnya itu. ${ }^{20}$

Sekalipun kata farihan dalam Q.S al-Baqqarah (2): 283, secara literal mengindikasikan bahwa rahn dilakukan oleh seseorang ketika dalam keadaan safar/ musafir. Hal ini, bukan berarti dilarangnya kegiatan tersebut bila dilakukan oleh orang

12 Muhammad Fuad Abd al-Baqi, al-Mu'jam al-Mufahras li al-Fâdz al-Qurân al-Karîm, Dar al-Hadits, Kairo, 2007.

1313

14

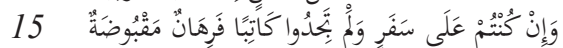

16 Ade Sofyan Mulazid, Kedudukan Sistem Pegadaian Syariah, Kencana Prenada Media Group, Jakarta, 2016, hlm. 5 .

17 Ibid.

18 Muhammad Ali Sayis, Tafsîr Âyât al-Ahkâm, t.p, t.t, t.th, hlm. 175.

19 Ade Sofyan Mulazid, Op. Cit., hlm. 6.

20 Muhammad Ali Sayis, Op. Cit., hlm. 176. 
yang menetap (bermukim). Sebab, keadaan musafir ataupun menetap bukanlah syarat kebasahan suatu transaksi rahn, melainkan contoh ekstrem dalam bertransaksi. Hal itu, dikuatkan dengan hadis yang mengisahkan bahwa Rasulullah Saw menggadaikan baju besinya kepada seorang Yahudi, untuk mendapatkan makanan bagi keluarganya, pada saat beliau tidak melakukan perjalanan. ${ }^{21}$

Zainuddin Ali menyatakan bahwa paling tidak ada 4 (empat) hadis yang dijadikan sebagai dasar rumusan rahn, yaitu sebagai berikut:

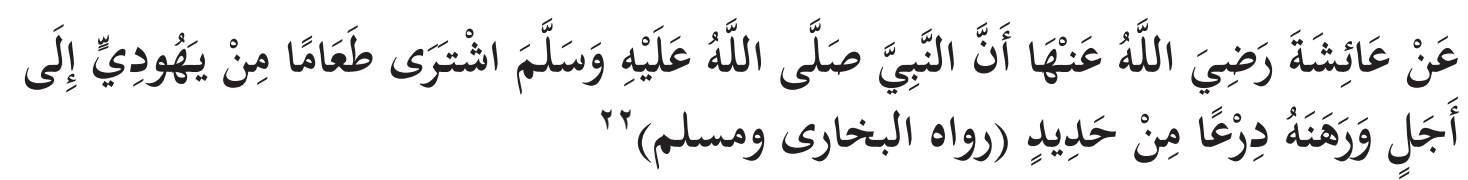

Dari 'Aisyah radliallahu 'anha bahwa Nabi shallallahu 'alaihi wasallam pernah membeli makanan dari orang Yahudi yang akan dibayar Beliau pada waktu tertentu di kemudian hari dan Beliau menjaminkannya (gadai) dengan baju besi. (H.R Bukhari dan Muslim).

Mayoritas ulama sepakat mengenai kebolehan hukum rahn. Hal dimaksud, didasarkan pada kisah Rasulullah Saw yang menggadaikan baju besinya untuk mendapatkan makanan dari orang Yahudi. Para ulama juga mengambil indikasi dari contoh tersebut, ketika beliau beralih dari yang biasanya bertransaksi kepada para sahabat yang kaya kepada seorang Yahudi, bahwa hal itu tidak lebih sebagai sikap Nabi yang tidak mau memberatkan para sahabat. Mereka biasanya enggan mengambil ganti ataupun harga yang diberikan oleh Nabi. Mayoritas ulama berpendapat bahwa rahn tidak saja disyariatkan pada waktu tidak bepergian. Hadis-hadis di atas dijadikan argumentasi untuk pendapat tersebut. Transaksi gadai tidak hanya dilakukan pada masa perjalanan, akan tetapi dapat dilakukan juga pada masa tidak bepergian. ${ }^{23}$

Kesan bahwa transaksi utang-piutang hanya dilakukan dalam perjalanan, sebagaimana Q.S al-Baqarah (2): 283 yang menyatakan bahwa transaksi rahn dilakukan pada waktu bepergian. Hal ini terjadi dikarenakan sering munculnya kebutuhan yang mendesak dalam perjalanan. Sedangkan untuk mencai saksi atau petugas pencatat (notaris) sulit ditemukan pada saat sedang dalam perjalanan. ${ }^{24}$

Para ulama telah menelaah apa kaidah hukum yang bisa dilakukan untuk kegiatan transaksi rahn. Menurut al-Suyuthi sebagaimana dikutip oleh Ade Sofyan Mulazid, kebolehan praktik rahn didasarkan pada kaidah hukum yang berbunyi "al-Ashlu fî al-Asyâ al-Ibâhah". Berbeda dengan al-Suyuthi, Ibn Nujaim mengatakan bahwa pada dasarnya dalam muamalah adalah haram sampai ada ketegasan dalil yang memerintahkannya. Lebih lanjut Ibn Nujaim merinci bahwa sebagian pengikut Hanafi ada yang seoendapat dengan Syafi'iyah seperti Imam al-Kurkhi. Sebagain lain, menyatakan pada asalnya adalah tawaqquf mesti ada penetapan atau kejelasan hukum. Menurut Ibn Qudamah alasan dibolehkannya rahn adalah adanya kemaslahatan yang terlepas (mashlahah almursalah). Kemaslahatan yang terkandung di dalam rahn, yaitu membantu antar sesama manusia. $^{25}$

Abu Yusuf sebagaimana dikutip oleh Ade Sofyan Mulazid berpendapat bahwa untuk meningkatkan taraf hidup masyarakat yang dilakukan dalam bentuk qardl al-hasan. Tujuan utamanya adalah memenuhi kebutuhan masyarakat yang kurang mampu melalui

21 Ade Sofyan Mulazid, Op. Cit., hlm. 6.

22 Muhammad Ibn Isma'il Ibn Ibrahim Ibn al-Mughirah al-Bukhari Abu Abdullah, Shahîh $\underline{h}$ al-Bukhâ̂, Dar al-Fikr, Beirut, 2005, Juz. Hlm. lihat juga, Muslim Ibn al-Hajaj Abu al-Hasan al-Qusyairi al-Naisaburi, Sha ĥh $\underline{h}$ Muslim, Dar al-Hadits, Kairo, Juz. Hlm.

23 Ade Sofyan Mulazid, Loc. Cit., hlm. 7.

24 Abu Abdullah Ibn Ahmad Ibn Abu Bakar Ibn Farah al-Anshari al-Khazraji Syams al-Din al-Qurthubi, Jâmi alAhkâm al-Qurân, Dar al-Hadits, Kairo, 2002, Juz. II, hlm. 346.

25 Ade Sofyan Mulazid, Op. Cit., hlm. 8. 
instrumen badan usaha publik (milik negara) yang sesuai prinsip-prinsip hukum Islam. Ia merekomendasikan kepada badan usaha publik untuk memaksimalkan pemenuhan kebutuhan masyarakat melalui optimalisasi pendapatan negara. Bagi Abu Yusuf tanggung jawab seorang pemimpin dapat dilihat dari upaya mensejahterakan masyarakat (kebijakan publik). ${ }^{26}$

Pegadaian dengan skim al-qardl al-hasan dapat dilakukan dalam kasus-kasus dimana infak dan shadakah tidak lagi memberikan manfaat besar kepada penerimanya. Di satu sisi infak dan shadakah menimbulkan masalah kehormatan daripada peminjam dan di sisi lainnya, hal itu akan mengurangi dorongan peminjam untuk berjuang dan berusaha. Tanggung jawab ini beralih kepada satuan keluarga, kelurahan, kecamatan bahkan sampai kepada negara, seperti halnya mendirikan Pegadaian Syariah oleh negara. ${ }^{27}$

Fatwa yang dijadikan rujukan dalam gadai syariah, yaitu: (1) Fatwa Dewan Syariah Nasional No. 25/DSN-MUI/III/2002 tentang Rahn; (2) Fatwa Dewan Syariah Nasional No. 26/DSN-MUI/III/2002 tentang Rahn Emas; dan (3) Fatwa Dewan Syariah Nasional No. 68/DSN-MUI/III/2008 tentang Rahn Tasjili. Fatwa yang dikeluarkan oleh DSN ini menjadi rujukan yang berlaku umum serta mengikat bagi lembaga keuangan syariah yang ada di Indonesia, demikian pula mengikat bagi masyarakat yang bertransaksi dengan Pegadaian Syariah. ${ }^{28}$

Dari uraian di atas dapat disimpulkan bahwa legalitas gadi telah memiliki dasar pijakan yang kuat karena didukung oleh dalil-dalil yang didasarkan pada al-Quran, sunnah, ijmak ulama, dan fatwa DSN-MUI. Oleh sebab itu, pegadaian saat ini harus melampaui tradisi gadai yang dibangun pada masa Rasulullah Saw. Pengembangan gadai menjadi sebuah lembaga keuangan mendapatkan keuntungan (profit oriented) merupakan salah satu jawaban di samping misi sosialnya. ${ }^{29}$

\section{c. Rukun dan Syarat Rahn}

Rukun rahn ada empat, yaitu pemberi gadai (Raahin), penerima gadai (murtahin), barang jaminan (marhuun), dan utang (marhuun bihi). Sementara rukun rahn adalah dua pihak yang berakad, akad rahn, barang jaminan (marhuun), dan utang (marhun bihi). Menurut Hanafiyah rukun rahn adalan ijab dan kabul dari raahin dan murtahin. ${ }^{30}$

Dalam setiap akad, unsur dan rukunnya harus memenuhi syarat. Berkaitan dengan rahn, syarat bagi para pihak yang berakad sama dengan syarat dalam akad lainnya. Syarat tersebut adalah para pihak harus berakal, sudah baligh, tidak dalam paksaan atau tidak terpaksa. Pasal 330KHES menyebutkan bahwa para pihak yang melakukan akad gadai harus sudah cakap hukum. Cakap hukum disini berarti berakal, sudah dewasa atau baligh serta tidak dalam paksaan.

Terkait syarat sigat atau akad, kalangan Hanafiyah mensyaratkan agar akad tidak terikat dengan syarat- syarat misalnya, penerima mau melaksanakan akad dengan syarat pemberi jaminan mau membeli barang tertentu miliknya. Sementara akad yang digantungkan dengan suatu kejadian dimasa mendatang misalnya akad rahn berlangsung selama tidak turun hujan, apabila turun hujan, maka akad tidak jadi. Adanya persyaratan dan penggantungan akad dengan sesuatu yang lain diluar akad maka akan membuat akad tersebut rusak

Syarat yang terkait dengan utang adalah, pertama, utang adalah hak yang harus dibayar. Kedua, jumlah melebihi dari nilai barang yang menjadi jaminan. Ketiga, hak utang harus jelas. Kalangan Syafiiyah dan Hambaliyah mensyaratkan (1) utang 
merupakan utang yang tetap dan wajib dibayar oleh raahin. (2) utang harus mengikat keduabelah pihak. (3) jumlah, ukuran dan sifat utang harus jelas diantara para pihak yang berakad.

Berdasarkan kesepakatan ulama, syarat yang terkait dengan barang yang digadaikan atau yang menjadi jaminan utang adalah sama halnya dengan syarat barang yang menjadi objek jual beli. Hal karena barang jaminan tersebut harus dapat dijual oleh penerima jaminan atau (murtahin) disaat orang yang menggadaikan tidak mampu membayar utangnya. Syarat-syarat yang terkait dengan barangyang menjadi objek jual beli adalah: ${ }^{31}$

1) Barang yang di gadai harus benar-berar ada dan nyata.transaksi terhadap barang yang belum atau tidak ada tidak sah, begitu juga barang yang belum pasti adanya, seperti binatang yang masih didalam kandungan induknya.

2) Objek transaksi berupa barang yang dinilai, halal, dapat dimiliki, dapat disimpan dan dimanfaatkan sebagaimana mestinya serta tidak menimbulkan kerusakan.

3) Barang yang dijadikan objek transaksi merupakan hak milik secara sah dan kepemilikan sempurna. Berdasarkan syarat ini, maka tidak sah menggadaikan pasir ditengah padang atau air laut yang masih dilaut atau menggadaikan panas matahari, karena tidak adanya kepemilikan yang sempurna.

4) Objek harus dapat diserahkan saat transaksi. Berdasarkan syarat ini maka tidak sah menggadaikan binatang liar, ikan dilautan atau burung yang ada di awing, karena tidak dapat diserahkan kepada pembeli.

5) Selain syarat diatas, ada satu syarat lagi yang mutlak harus terpenuhi, yaitu barang yang digadaikan harus tahan lama dan tidak mudah rusak, seperti emas, perak, logam mulia, kendaraan dan seterusnya. Berdasarkan syarat ini, maka tidak sah menjadikan maknan yang mudah busuk, seperti kue basah sebagai jaminan utang, karena tidak bertahan lama.

Menurut ulama Hanafiyah, syarat barang yang digadaikan harus barang yang berharga, jelas, dan diserahterimakan, dapat disimpan tahan lama, terpisah dari barang lainnya, baik benda bergerak maupun tidak. Secara lebih rinci, syarat-syarat ini dapat dijelaskan sebagai berikut: ${ }^{32}$

1) Barang yang digadaikan harus dapat diperjualbelikan; harus pada waktu akaddan dapat diserahterimakan;

2) Barang yang digadaikan harus berupa harta (kekayaan) yang bernilai;

3) Barang yang digadaikan harus halal digunakan atau dimanfaatkan, sekiranya barang tersebut dapat untuk melunasi utang;

4) Barang harus jelas, spesifikasinya, ukuran, jenis jumlah, kualitas dan seterusnya;

5) Barang harus milik pihak yang menggadaikan secara sempurna;

6) Barang yang digadaikan harus menyatu, tidak terpisah-pisah;

7) Barang harus tidak ditempeli sesuatu yang tidak ikut digadaikan;

8) Barang yang digadaikan harus utuh; tidaksah menggadaikan mobil hanya seperempat atau separuh.

Rahn dikatakan sah apabila telah memenuhi rukun dan syarat sebagaimana dijelaskan diatas. Apabila salah satu rukun atau syarat tidak terpenuhi, maka rahn tidak sah.

\section{Prinsip-Prinsip Sayriah dalam Akad Rahn pada Lembaga Pegadaian Syariah}

Secara substantif, Pegadaian Syariah memiliki 3 (tiga) prinsip yang bersumber pada kajian ekonomi Islam. Prinsip pengembangan ekonomi tidak saja mengacu pada proses

32 Imam Mustofa, Fiqih Muamalah Kontemporer, PT RajaGrafindo Persada, Jakarta, 2016, hlm. 198. 
di mana masyarakat dari suatu negara memanfaatkan sumber daya yang tersedia untuk menghasilkan kenaikan produksi barang dan jasa secara terus-menerus. Akan tetapi, Islam memiliki prinsip-prinsip pengembangan yang dibingkai dengan kerangka hubungan dengan Allah dan menyeimbangkan antar-kehidupan di dunia dan di akhirat. Di antara prinsip-prinsip tersebut adalah sebagai berikut: ${ }^{33}$

\section{a. Prinsp Tauhid (Keimanan)}

Tauhid merupakan pondasi ajaran Islam. Dalam pokok ajaran ini, menyatakan bahwa Allah adalah pencipta alam semesta dan segala isinya dan sekaligus pemiliknya termausk manusia dan seluruh sunber daya yang ada. Karena itu Allah adalah pemilik hakiki, sedangkan manusia hanya diberi amanah untuk "memiliki" untuk sementara waktu, sebagai ujian bagi mereka. ${ }^{34}$

Dalam Islam, segala sesuatu yang ada tidak diciptakan dengan sia-sia, tetapi memiliki tujuan (Q.S 23: 115). Salah satu tujuan diciptakan manusia adalah untuk beibadah kepadaNya (Q.S 51: 56). Karena itu segala aktivitas manusia dalam hubungannya dengan sumber daya alam dan manusia (muamalah) dibingkai dengan kerangka hubungan dengan Allah. ${ }^{35}$

Tauhid itu membentuk 3 (tiga) pokok filsafat ekonomi Islam, yaitu: pertama, dunia dengan segala isinya adalah milik Allah dan berjalan menurut kehendak-Nya (Q.S 5: 20 dan Q.S 2: 6). Manusia sebagai khalifah-Nya hanya mempunyai hak khilafat dan tidak bersifat absolut, serta harus tunduk melaksanakan hukum-Nya, sehingga mereka yang menganggap kepemilikan secara tidak terbatas, berarti ingkar kepada kekuasaan Allah Swt. Implikasi dari status kepemilikan menurut Islam adalah hak manusia atas barangbarang atau jasa-jasa itu terbarbatas. Hal ini jelas berbeda dengan kepemilikan mutlak oleh individu pada sistem kapitalis dan kaum ploteral pada sistem Maexisme. ${ }^{36}$

Kedua, Allah Saw adalah pencipta semua makhluk, dan semua makhluk tunduk kepada-Nya (Q.S 6: 142-145; Q.S 16: 10-16; Q.S 35: 27-29; dan Q.S 39:21). Dalam Islam, kehidupan dunia hanya dipandang sebagai ujian, yang akan diberikan ganjaran dengan surga yang abadi. Menurut Tarek El-Diwany, ganjaran atas usaha-usaha dunia yang terbatas dan non moneter hal inilah yang sulit untuk dimasukkan ke dalam analisis ekonomi konvensional. ${ }^{37}$ Sedangkan ketidakmerataan karunia nikmat dan kekayaan yang diberikan Allah Swt kepada setiap makhluk-Nya, merupakan kekuasaan Allah Swt semata. Tujuannya adalah agar mereka yang diberi kelebihan sadar menegakan persamaan masyarakat (egalitarian) dan bersyukur kepada-Nya (Q.S 107: 1-7; dan Q.S 11: 7), persamaan dan persaudaraan dalam kegiatan ekonomi, yakni syirkah dan qiradh atau bagi hasil (Q.S 2: 254 dan Q.S 5: 2). Doktrin egalitarianisme Islam seperti itu, berbeda dengan sistem ekonomi materialistik, hedonis yang prolater sosialistik dan marxisme. $^{38}$

Ketiga, iman kepada hari kiamat akan mempengaruhi tingkah laku ekonomi manusia menurut horizon waktu. Sedangkan muslim yang melakukan aksi ekonomi tertentu, akan mempertimbangkan akibatnya pada hari kemudian. Menurut dalil ekonomi, hal ini mengandung maksud bahwa dalam memilih kegiatan ekonomi haruslah mempertimbangkan baik menghitung nilai sekarang maupun hal yang akan dicapai di

\section{Ibid., hlm. 21.}

34 Abdul Gahofur Anshori, Gadai Syariah Di Indonesia: Konsep, Implementasi dan Institusionalisasi, Gadjah Mada University Press, Yogyakarta, 2011, hlm. 102.

35 Ibid.

36 Sasli Rais, Pegadaian Syariah: Konsep dan Sistem Operasional (Suatu Kajian Kontemporer), UI Press, Jakarta, 2008, hlm. 23.

37 Tarek El-Diwany, The Problem With Interest, diterjemahkan Amdiar Amir, Cetakan I, Akbar Media, Jakarta, 2003, hlm. 160.

38 Salsi Rais, Op. Cit., hlm. 24. 
masa yang akan datang. Hasil kegiatan mendatang ialah semua yang diperoleh, baik sebelum maupun sesudah mati (extended time horizon), seperti yang dijelaskan dalam Q.S 75: 1-10; dan Q.S 99: 1-8. ${ }^{39}$

Prinsip tauhid dapat mengukuhkan konsep non-materialistik dan dipahami sebagai triangle, dimana ketaatan kepada Tuhan diletakan pada posisi puncak, sedangkan manusia dab alam diletakan pada posisi sejajar yang saling membutuhkan. Manusia diberikan amanat untuk memanfaatkan alam (sebagai resources) dan di dorong untuk menghasilkan output yang dapat bermanfaat bagi semua pelaku ekonomi. Output itu sensiei tidak mutlak dimilikinua karena pada harta yang dimilikinya ada hak orang lain yang membutuhkannya. ${ }^{40}$

Studi tentang pembiayaan tidak lepas dari kegiatan yang dilakukan untuk memanfaatkan dan mengembangkan harta. ${ }^{41}$ Pengembangan kekayaan dalam ekonomi konvensional menganut prinsip yang mengacu kepada teori bunga. ${ }^{42}$ Ajaran Islam memandang bahwa harta serta pengembangannya tidak bisa diakumulasi dengan cara riba sebagai teori bunga. Pada saat yang sama, kebiasaan untuk mendiamkan harta yang diperoleh tidak pula dianjurkan dalam Islam. Ketika seseorang memiliki harta kemudian mendiamkannya (idle assets), maka akan menyebabkan harta tersebut hanya dimiliki oleh segelintir orang kaya. Pada akhirnya, jurang antara si kaya dan si miskin akan semakin menganga. Padahal, dalam harta milik seseorang (property rights) ada hak milik orang lain. Hal ini menunjukan bahwa Islam menghdendaki terjadinya perputaran kepemilikan harta secara lebih mereta. ${ }^{43}$

Sistem pegadaian yang dianut ekonomi Islam selama ini didasarkan pada 2 (dua) sifat, yaitu: (1) konsumtif; dan (2) produktif. Pembiayaan konsumtif dapat dilakukan dengan pendekatan: (a) sistem margin (keuntungan) melalui akad al-murâbahah (jual beli tangguh); dan (b) sistem pinjaman tanpa bunga melalui akad al-qard al-hasan atau yang lebih dikenal dengan pinjaman kebajikan. Adapun pembiayaan produktid dapat dilakukan dengan pendekatan sistem bagi hasil (profit and loss-sharing) melalui akad al-mudhârabah (kemitraan pasif); dan akad al-musyârakah (kemitraan aktif). ${ }^{44}$

\section{b. Prinsip Ta'âwun (Tolong-Menolong)}

Abu Yusuf (w. $182 \mathrm{H}$ ) dalam al-Kharaj menyebutkan bahwa prinsip yang harus diletakan dalam transaksi gadai adalah ta'awun (tolong-menolong), yaitu prinsip saling membantu antar sesama dalam meningkatkan taraf hidup melalui mekanisme kerja sama ekonomi dan bisnis. Hal ini sesuai dengan Al-Quran "Dan tolong-menolonglah kamu dalam berbuat kebajikan dan takwa serta janganlah bertolong-menolong dalam berbuat keji dan permusuhan." (QS. Al-Maaidah (4): 2). Realitas prinsip ta'awun pada transaksi gadai mengindikasikan ikatan kuat antara tradisi manusia dengan agama yang muncul akibat konsekuensi logis terhadap berkembangnya aktivitas manusia yang bergerak secara cepat. ${ }^{45}$ Prinsip ini juga telah disampaikan Abu 'Ubaid (w. 224 H) dalam al-Amwal. Ia

39 Ibid.

40 Ade Sofyan Mulazid, Loc. Cit., hlm. 24.

41 Konsep Islam sejak klasik mengantarkan pembangunan ekonomi lebih luas dari konsep sekuler. Pembangunan ekonomi dalam Islam bukan hanya memacu pembangunan material, namun juga segi spiritual dan moral yang menempati kedudukan yang sangat penting. Karena itu, pengelolaan keuangan negara sebagai alat pembangunan fisik dan nonfisik dapat digerakan melalui proses rahn. Lihat, Ade Sofyan Mulazid, hlm,. 24.

42 Teori bunga dapat digolongkan pada 2 (dua) kelompok yang terdiri atas: (1) teori bunga murnil dan (2) teori bunga moneter. Pada teori bunga murni termauk di dalamnya teori bunga klasik, teori bunga tahan nafsu (abstinence theory of interest), teori bunga produktivitas (productivity theory of interest) dan teori bunga Asutria. Adapun teori bunga moneter yang terdiri dari: teori bunga tentang dana yang dapat dipinjamkan (the loanable funds theory of interest) dan teori bunga Keynes.

43 Ibid., hlm. 25.

44 Ibid.

45 Abu Yu suf Ya'kub Ibn Ibrahim, al-Kharaj, Kairo, Al-Mathabaah al-Salafiyah, t.t, hlm. 34. 
berpandangan bahwa prinsip ta'awun sesama manusia dapat meningkatkan taraf hidup. ${ }^{46}$ Menurut Sa'id Sa'ad Martan, prinsip ini berorientasi pada sosial adalah usaha seseorang untuk membantu meringankan beban saudaranya yang ditimpah kesulitan melalui gadai syariah. ${ }^{47}$

\section{c. Prinsip Bisnis (Tijârah)}

Afzalur Rahman menyatakan bahwa bisnis (perdagangan) adalah suatu kegiatan yang dianjurkan dalam Islam. ${ }^{48}$ Nabi sering kali menekankan pentingnya bisnis dalam kehidupan manusia. ${ }^{49}$ Namun demikian, dalam mencari laba harus dengan cara yang dibenarkan oleh syariah. Hal ini bertujuan agar kesejahteraan tercapai. Umar Chapra menyebutnya dengan istilah al-Falah. ${ }^{50}$ Muhammad Syafi'i Antonio berpendapat dalam kacamata Islam tidak ada dikotomi antara usaha-usaha untuk pembangunan ekonomi maupun sektor-sektor lainnya dengan persiapan untuk kehidupan di akhirat nanti. ${ }^{51}$ Karena itu, kegiatan bisnis gadai syarikah, tanpa mengikuti aturan-aturan syariah, maka akan membawa kehancuran.

Prinsip-prinsip bisnis di atas, menjadi pedoman dalam usaha pegadaian sepanjang masa. Karena itu, prinsip-prinsip usaha pegadaian ialah: (1) harus didasari sikap saling ridha di antara kedua belah pihak, sehingga para pihak tidak merasa diruagikan atau dizalimi; (2) menegakkan prinsip keadilan dalam proporsi keuntungan; (3) kegiatan bisnis tidak melakukan investasi pada usaha yang diharamkan seperti usaha-usaha yang merusak mental dan moral; (4) bisnis harus terhindar dari praktik gharar (ketidakpastian), tadlis (penipuan) dan masyir (judi); serta (5) dalam kegiatan bisnis, baik utang-piutang maupun bukan, hendaklah dilakukan pencatatan (akuntansi).

Dengan demikian, ketiga prinsip di atas menjadi acuan dasar dalam pengembangan Pegadaian Syariah, serta penerapannya dalam kehidupan so sio-ekonomi. Kurang kuatnya salah satu dasar tersebut, maka akan menyebabkan lambatnya gerak pengembangan lembaga bisnis itu sendiri, serta tidak akan mampu mencapai kesejahteraan hidup. Oleh karena itu, perlu dijelaskan mengenai perbedaan antara Pegadaian Syariah dengan pegadaian konvensional.

\section{PENUTUP}

Berdasarkan uraian di atas, maka dapat ditarik beberapa kesimpulan sebagai berikut: pertama, konsep gadai dalam literatur fikih klasik dinamai dengan istilah rahn, landasan yuridis kebasahan transkasi/akad gadai dalam Islam terdapat dalam al-Quran surat al-Baqarah: 283, yang secara eksplisit menerangkan hukum gadai, selain terdapat di dalam al-Quran landasan yuridis keabsakan akad gadai/rahn terdapat di dalam beberapa hadis Nabawi serta konsensu/ijmâ' para ulama tenteng hal tersebut; kedua, prinisp-prinsip syariah di diterapkan dalam sistem pegadaian syariah ada 3 (tiga) prinsip, yaitu: prinsip tauhid, prinsip tolong-menolong (ta'awun) dan prinsip bisnis (tijariah).

46 Abu 'Ubaid, al-Amwal, Kairo, Dar al-Fikr, 1975, hlm. 166.

47 Sa'id Sa'ad Martan, Madkhal li al-fikri al-Iqtisadi al-Islami, Beirut, Mu'assasah al-Risalah, 1999, hlm.76.

48 Afzalur Rahman, Muhammad a TraderLahore, Islamic Publication, 1995, hlm. 25-42.

49 Artinya, "Hendaklah kamu berdagang, karena di dalamnya terdapat 90\% pintu rejeki" (HR.Ahmad). Lihat: Imam Jalaludin bin Abi Bakar As-Suyuthi, al-Jam'i Ash-Shaghir, Beirut, Darul Kutub al-Ilmiyah, tt, Juz. I, hlm. 341.

50 M. Umer Chapra, Islam and The Economic Challenge, USA, The International Institute of The Islamic Thought, Edisi Indonesia, Islam dan Tantangan Ekonomi, Yogyakarta, Dhana Bhakti Wakaf, 1995, hlm. 220.

51 Muhammad Syafi'i Antonio, (Ed.,) Mustafa Kamal, "Potensi dan Peran Sistem Ekonpmi Islam dalam Upaya Pembangunan Umat Islam Nasional dan Global” dalam Wawasan Islam dan Ekonomi Sebuah Bunga Rampai, Jakarta, Lembaga Penerbitan Fakultas Ekonomi Universitas Indonesia, 1997, hlm. 182. 


\section{DAFTAR PUSTAKA}

Abdul Gahofur Anshori, Gadai Syariah Di Indonesia: Konsep, Implementasi dan Institusionalisasi, Gadjah Mada University Press, Yogyakarta, 2011

Abu Abdullah Ibn Ahmad Ibn Abu Bakar Ibn Farah al-Anshari al-Khazraji Syams al-Din alQurthubi, Jâmi al-Ahkâm al-Qurân, Dar al-Hadits, Kairo, 2002.

Abu 'Amr Yusuf Ibn Abdullah Ibn Muhammad Ibn Abd al-Bar Ibn Ashim al-Numari al-Qurthubi, al-Kâfî fî Fiqh ahl al-Madînah al-Mâlikî, Maktabah al-Riyadh al-Hadistah, Saudi Arabia, 1980.

Abu Bakar Ibn al-Sayyid Muhammad Syatha al-Dimyathi, I'ânt al-Thâlibîn 'alâ hil al-Fâdz Fath al-Mu'în Lisyarh Qurra al- 'Ain, Dar al-Fikr, Beirut, t.th.

Abu Muhammad Abdullah Ibn Ahmad Ibn Muhammad Ibn Qudamah al-Maqdisi, al-Mughî wa yalihi al-Syrah al-Kabîr, Dar al-Hadits, Kairo, 2004.

Abu 'Ubaid, al-Amwal, Kairo, Dar al-Fikr, 1975.

Abu Yu suf Ya'kub Ibn Ibrahim, al-Kharaj, Kairo, Al-Mathabaah al-Salafiyah, t.th.

Abu Zakariya Yahya Ibn Syarif al-Nawawi, Mughni al-Muhtâj, Musthafa al-Babi al-Halabi, Mesir, 1957.

Ade Sofyan Mulazid, Kedudukan Sistem Pegadaian Syariah, Kencana Prenada Media Group, Jakarta, 2016.

Afzalur Rahman, Muhammad a Trader Lahore, Islamic Publication, 1995.

M. Umer Chapra, Islam and The Economic Challenge, USA, The International Institute of The Islamic Thought, Edisi Indonesia, Islam dan Tantangan Ekonomi, Yogyakarta, Dhana Bhakti Wakaf, 199.

Manshur Ibn Yunus Ibn Idris al-Buthi, Kasyf al-Qinâ' ' an matan al-Iqnầ', t.p, tt, tth.

Muhammad Fuad Abd al-Baqi, al-Mu'jam al-Mufahras li al-Fâdz al-Qurân al-Karîm, Dar alHadits, Kairo, 2007.

Muhammad Ibn Isma'il Ibn Ibrahim Ibn al-Mughirah al-Bukhari Abu Abdullah, Shahîh $\underline{h}$ al-Bukhâî, Dar al-Fikr, Beirut, 2005.

Muhammad Ridwan, Manajemen Baitul Maal Wa Tamwil (BMT), UII Press, Yogyakarta, 2004.

Muhammad Syafi'i Antonio, (Ed.,) Mustafa Kamal, "Potensi dan Peran Sistem Ekonpmi Islam dalam Upaya Pembangunan Umat Islam Nasional dan Global" dalam Wawasan Islam dan Ekonomi Sebuah Bunga Rampai, Jakarta, Lembaga Penerbitan Fakultas Ekonomi Universitas Indonesia, 1997.

Muslim Ibn al-Hajaj Abu al-Hasan al-Qusyairi al-Naisaburi, Shahhh Muslim, Dar al-Hadits, Kairo. Imam Mustofa, Fiqih Muamalah Kontemporer, PT RajaGrafindo Persada, Jakarta, 2016.

Jalaludin bin Abi Bakar As-Suyuthi, al-Jam'i Ash-Shaghir, Beirut, Darul Kutub al-Ilmiyah, tt,

Kasmir, Bank dan Lembaga Keuangan Lainnya, Rajawali Press,Jakarta, 1998.

Louis Maluf, al-Munjid Lughah wa al-A'lâm, Dar al-Masyark, Beirut, 1986.

Sa'id Sa'ad Martan, Madkhal li al-fikri al-Iqtisadi al-Islami, Beirut, Mu'assasah al-Risalah, 1999.

Sasli Rais, Pegadaian Syariah: Konsep dan Sistem Operasional (Suatu Kajian Kontemporer), UI Press, Jakarta, 2008. 
Tarek El-Diwany, The Problem With Interest, diterjemahkan Amdiar Amir, Cetakan I, Akbar Media, Jakarta, 2003.

Taqiyuddin Abu Bakar al-Husaini, Kifâtat al-Akhyâr fî Hall al-Ikhtishâr, Dar al-Khair, Damaskus, 1994.

Wahbah al-Zuhaili, al-Fiqh al-Islâmî wa Adllatuh, Dar al-Fikr, Beirut, 2012. 